\title{
Coir Pith as Growth Medium for Azotobacter Vinelandii and Azospirillum Brasilense
}

\author{
Abesh Reghuvaran $^{1}$ and Anita Das Ravindranath ${ }^{2}$
}

\begin{abstract}
Coir pith is a lignocellulosic biomass which is recalcitrant under ordinary conditions. Nitrogen fixation is commonly carried out in the soil and these soils acts as the medium for plant growth. This paper attempts to utilize coir pith as a substrate for two important nitrogen fixing organisms viz. Azotobacter vinelandii and Azospirillum brasilense. Coir pith was used as a source of carbon and energy by the bacteria and the ammonia produced during the process of nitrogen fixation was studied, the amount of ammonia produce indicates the fixation process by the bacteria. The present work succeeded in establishing the use of these two organisms to degrade the coir pith effectively and the resultant biodegraded material could be used as organic manure for plants.
\end{abstract}

Key words: Coir pith, Nitrogen fixation, Biodegradation, ammonia.

\footnotetext{
${ }^{1}$ Senior Research Fellow, Rajiv Gandhi Chair in Contemporary Studies, School of Environmental Studies, Cochin University of Science \& Technology, Cochin 682 022, Eranakulam, Kerala, India.

Email.abesh199@gmail.com

${ }^{2}$ Senior Scientific Officer, Central Coir Research Institute, Kalavoor. P. O, Alappuzha, Kerala, India.

Email.anitadas30@gmail.com
} 


\section{Introduction}

Coir pith is the name given to the dust left behind after the industrially valuable long fiber of coir has been extracted from the coconut husk. It is a fluffy, spongy material with significant water holding capacity and is extremely compressible (Vijaya et al, 2008). Coconut husk is the basic raw material for the coir industry (Reghuvaran et al, 2009). Coir fibre extracted from husk is used in local beddings, mattings, rubberized coir mattress, yarns, in rope making etc. After extraction of coir fibre from husk, the remaining material (coir pith) remains as a byproduct. Coir pith constitutes as much as $70 \%$ of the coconut husk and has a high water holding capacity of 8 times of its weight. Interest in nitrogen fixation mainly in the sea has usually been focused on rates of nitrogen fixation, but information on the types of species present with the capability for nitrogen fixation can be important for predicting nitrogen fixation rates in situ (Zehr et al., 1998)

The coir pith contains about 35\% lignin which is an aromatic polymer composed of phenyl propane subunits including coumaryl, guaicyl and syringyl moieties that are covalently linked together by a variety of bonds, but mainly by beta-aryl ether bonds. It is also present in the fibres and is responsible for the stiffness of coir. It is thought that the lignin has its origin in carbohydrates. It is mainly a hard substance and is almost free from degradation in ordinary conditions. It should be noted that coir pith is resistant to biodegradation due to the presence of lignin. Normally coir pith is dumped as agricultural waste and accumulates as a waste product as heaps of course and fine dust (Ghosh et al, 2007). The coir pith decomposes very slowly in soil as its pentosan-lignin ratio is below 0.5, and because of chemical and structural complexity of lignin-cellulose complex (Ramalingam et al, 2004). High content of lignin in coir pith causes very slow decomposition following which it is used as raw organic manure for crops (Vinodhini et al, 2005).

The study of coir pith degradation with bacteria is very limited due to its poor degrading ability to degrade lignin present in it. Janshekar, $\mathrm{H}$ and Fiechter (1981) reported some bacterial culture was tested for the degradation of lignin which has the ability to degrade numerous phenols with structural relationship to lignin. The poor degradation of lignin was observed in all tested bacteria, they also commented that the poor degradation does not seem to be influenced by the medium composition and culture condition but is more probably due to the inability of the tested bacteria to degrade lignin to any considerable extent. Instead of this, for many years, the filamentous blue-green algae (Cyanobacteria) were believed to be primarily responsible for nitrogen fixation in oceanic waters because low or negligible in situ rates were observed in their absence and there was a correlation of in situ nitrogen fixation with light intensity (Stewart, 1974). Some Cyanobacteria were capable of degrading the coir pith. Some enhanced techniques show the use of coir pith based cyanobacterial biofertilizer in sustainable integrated agro ecosystems (Prabha et al, 2009). So, this method can are useful to promote the growth of plant and increase the quality and quantity of crop yield (Hume, 2007). Most recently, cellulolytic nitrogen fixing bacteria have been isolated in large numbers, apparently as a pure culture, from a specialized gland found in ship worms (Waterbury et al., 1983). The work conducted by Anandharaj (2007) also shows the coir pith can be partially decomposed through the action of cyanobacteria and can be used as biofertilizer for all varieties of food crops.

Nitrogen fixation is the reduction of atmospheric nitrogen to NH3 (ammonia). Free living prokaryotes with the ability to fix atmospheric dinitrogen (diazotrophs) are ubiquitous in soil. The free living diazotrophs are subclassified. Aerobic diazotrophs, of which there are over 50 genera, including Azotobacter, methane-oxidizing bacteria and cyanobacteria require oxygen for growth and fix nitrogen when oxygen is present. Azotobacter, some related bacteria and some cyanobacteria fix nitrogen in ordinary air but most members of this group fix nitrogen only when the oxygen concentration is low. Free living diazotrophs, which fix nitrogen 
only when oxygen is absent or vanishingly low, are wide spread. In natural ecosystems, biological nitrogen fixation is most important source of nitrogen. The contribution of freeliving nitrogen fixing prokaryotes estimated to the nitrogen input of soil ranges from 0-60 $\mathrm{kg} / \mathrm{ha} /$ year (Burgmann et al., 2003). It is also evident that dinitrogen nitrogen fixers microorganisms (diazotrophs) play important roles in ocean biogeochemistry and plankton productivity (Church et al., 1999).

Newton and Cavins, 2003 studied the nitrogen fixation (acetylene reduction) and ammonia liberation in a facultatively heterotrophic cyanobacterium. Autotrophically grown cells lost acetylene reduction activity when incubated under anaerobic conditions; the activity was maintained in the presence of methionine sulfoximine or by pretreatment of the cells with a carbon supply. Heterotrophically grown cells maintained acetylene reduction activity anaerobically in the absence of methionine sulphoximine. Another important observation by Hans Brintzinger, 1966 stated that the reduction of molecular nitrogen to ammonia by aerobic and anaerobic microorganisms occurs through combined mediation of two nonheme iron particles, one of which contains, besides iron, molybdenum. Gina et al, 1992 isolated two new nitrogen fixing bacteria from the rhizosphere of mangrove trees. Biological nitrogen fixation is catalyzed by the enzyme nitrogenase, which is possessed by diverse microorganisms representing virtually all phylogenetic groups. Nitrogenase is composed of two oxygen-labile metallo protein namely dinitrogenase and dinitrogenase reductase. Dinitrogenase is a $240-\mathrm{KDa}$ alpha2-beta2 tetramer of the nifD and nifK gene products and dinitrogenase reductase is a $60-\mathrm{KDa}$ alpha2 dimer of the nifH gene products that contains a single $4 \mathrm{Fe}-4 \mathrm{~S}$ center coordinated between the two subunits (Rubio et al., 2005). Kennedy et al., 2004, also suggests understanding how fixed nitrogen regulates nitrogenase availability is necessary for devising strategies to increase the amount of ammonium synthesized by nitrogen fixing bacteria with the potential to be used in agriculture. In the case of A.vinelandii is complicated by the presence of three biochemically and genetically distant nitrogenase enzymes, each of which is synthesized under different conditions of metal supply. The regulation of conventional molybdenum nitrogenase, whose subunits are encoded by the Nif-HDK genes and which is similar to the enzymes purified from number of other nitrogen fixing organisms (Sabra et al., 2000).

Nitrogeneous fertilizers are one of the most widely used chemical fertilizers, as deficiency of nitrogen in the soil often limits crop yields (Sarita et al, 2008). Consumption of nitrogen fertilizer in Asia has increased from 1.5 to 47 million tonnes during the last 35 years (Dawe, 2000). Nitrogen fixation occurs in phyla from Archea and Eubacteria. These microorganisms possess the enzyme nitrogenase encoded by the nifK, nifD and nifH genes. These genes have been used to study phylogenetic relationship among nitrogen fixing bacteria (Young et al, 1992). Different techniques have been utilized to characterize the diversity of nifH gene pool identification from various environments, eg. Cloning of PCR-amplified products or by denaturing gradient gel electrophoresis, PCR based Restriction Fragment Length Polymorphism (RFLP), and flourescent labeled terminal restriction fragment length polymorphism (t-RFLP) (Poly et al, 2001).

From the earlier studies of the author states that the coir pith which is degraded with the combination of Mushroom species and Nitrogen fixing bacteria such as Azotobacter and Azospirillum cause definite reduction in the Lignin levels and increase the percentage of NPK in the coir pith. Thus the same can be used as effective organic manure. Of the various rhizosphere associated nitrogen fixing bacteria, Azospirillum species are probably the most studied and appear to have significant potential for commercial applications. These organisms, characterized by high nitrogen fixing ability, are found in abundant numbers in the rhizosphere as well as in the intercellular spaces of the roots of certain cereals and other plants (Bashan et al, 1997). Besides the nitrogen fixation, Azotobacter also produces Thiamine, Riboflavin, Indole 
acetic acid and Gibberelins. When Azotobacter is applied to seeds, seed germination is improved to a considerable extent, so also it controls plant diseases due to above substances produced by Azotobacter (Kader et al., 2002).

The present study estimates the efficacy of coir pith as a substrate for the growth of two important nitrogen fixing bacteria and thereby biodegrade coir pith for use as effective organic manure. This study therefore is an attempt to study the potential of this nitrogen fixing bacteria independent biodegradation, growth and action in coir pith. A consortium using this microflora with appropriate fungal species for composting helps in making coir pith a perfect soil conditioner and bio-organic manure for horticulture/Agriculture.

\section{Materials and Methods}

\section{Collection of Samples}

Coir pith samples were collected from accumulated stations of Alappuzha district, Kerala, India. The Bacterial samples were collected from Microbial Type Culture Collection (MTCC), Chandigarh (Azotobacter vinelandii, MTCC NO.124 and Azospirillum brasilense, MTCC NO.125) The composting process done in Rajiv Gandhi Chair in Contemporary Studies, School of Environmental Studies, Cochin University of Science and Technology (CUSAT). The biochemical estimations were carried out at Central Coir Research Institute, Alappuzha and Rajiv Gandhi Chair.

\section{Composting Process}

Three lots of coir pith (1 kg each) in duplicates were laid as separate heaps. Nitrogen fixing bacteria such as Azotobacter vinelandii and Azospirillum brasilense were thoroughly mixed with the second and third lots of coir pith respectively and the first sample kept as untreated. Nitrogen fixing bacteria were added in the phosphate buffer for mixing in the sample. Moisture content $(200 \%)$ was maintained and microbial growth has monitored regularly for 45 days, by drawing out samples at periodic intervals.

\section{Estimation of Ammonia}

Estimation of Ammonia in coir pith sample is done by Neslerization method. The sample is digested and buffered. The ammonia in the sample is treated with Nessler's reagent and measured photometrically at $440 \mathrm{~nm}$. Prepare a linear calibration curve using different concentrations of standard Ammonia solution which can be prepared from anhydrous ammonium chloride. $1 \mathrm{gm}$ of the sample is digested with 1:1 $\mathrm{HCl}$ and filtered; add $6 \mathrm{~N}$ $\mathrm{NaOH}$ solution to make $\mathrm{pH}$ of 10.5 and make up to a known volume. Then take $50 \mathrm{ml}$ of sample, add $2 \mathrm{ml}$ of Nessler's reagent and mix well. Let the reaction proceed for at least $10 \mathrm{~min}$. Then measure photometrically at $440 \mathrm{~nm}$. Calculate the concentration from the calibration graph

\section{Estimation of Nitrogen}

Nitrogen in the coir pith samples were estimated by Alkaline permanganate method using kjeldhal distillation unit (Vogel, 1961). The method includes Digestion, Distillation and Titration. Digestion process need following chemicals for every $0.2 \mathrm{gm}$ coir pith samples. Conc. H2SO4-10 ml, Catalyst mixture $\left(\mathrm{K}_{2} \mathrm{SO}_{4}\right.$ \& $\mathrm{CuSO}_{4}$ ) mixture in 50 and 10 gm proportions) take $3 \mathrm{gm}$ each. Adjust the temperature $420^{\circ} \mathrm{C}$ and the digestion time is 1 to 1.5 hours. Distillation process was done with $40 \% \mathrm{NaOH}$ and $4 \%$ Boric acid. After 9 minutes, the colour in the conical flask changes to pink colour to green. This is the end point of distillation. Then take conical flask for titration. Titration is done with $01 \mathrm{~N} \mathrm{H} 2 \mathrm{SO} 4$.Titrate with the distilled solution till the colour changes from green to permanent pale pink colour.

Percentage of Nitrogen $=$

$$
\frac{14 \times \text { titrant value } \times \text { Normality of Acid } \times 100}{1000 \times \text { sample weight }}
$$

\section{Estimation of Total Phosphorous}

Total phosphorous in the coir pith sample were estimated with Vanado Molybdo phosphoric yellow colour method. Dried and powdered coir pith sample $(0.5 \mathrm{~g})$ is taken in boiling tube. $15 \mathrm{ml}$ tri acid is added (mixture of Concentrated $\mathrm{HNO}_{3}, \mathrm{H}_{2} \mathrm{SO}_{4}$ and Perchloric acid 
in the ratio 10:1:4) and kept overnight and digest. The digested sample is quantitatively transferred to $100 \mathrm{ml}$ volumetric flask. It is make up to 100 $\mathrm{ml}$ with distilled water. Take $5 \mathrm{ml}$ in a $25 \mathrm{ml}$ volumetric flask and then $5 \mathrm{ml}$ of Vanado molybdate reagent is added and make up to 25 $\mathrm{ml}$ with distilled water. Shake thoroughly and read in spectrophotometer $(430 \mathrm{~nm})$ after $10 \mathrm{~min}$. Compare and estimate the value with standard curve.

Percentage of Phosphorous $=$

$$
\frac{100 \times 25 \times \mathrm{ppm} \text { (dilution) }}{0.5 \times 5 \times 10,000}
$$

\section{Estimation of Potassium}

It is done with Flame photometry. The estimation done by triple acid extract is diluted suitably to contain approximately 4-7 ppm. Read in the flame photometer after adjusting with standard (100 ppm, $50 \mathrm{ppm}$ and $20 \mathrm{ppm}$ ).

Percentage of Potassium $=\frac{\text { Reading } \times 100}{0.5 \times 10,000}$

Organic Carbon was estimated by Walkey and Black method (1934).

\section{Results and Discussion}

Nitrogen, Phosphorous, Potassium and Organic carbon in the coir pith before and after the biodegradation were estimated (Table $1 \& 2$ ). Ammonia reduction in the coir pith is the indication of Nitrogen fixation. The results of estimation of Ammonia are given in Table 3. The nitrogen in the composted coir pith (45 days) was observed to increase to $0.70 \%$ in the case of composting with Azotobacter vinelandii and to $0.61 \%$ in the case of Azospirillum brasilense from $0.19 \%$ nitrogen in raw coir pith. The values for each 10, 20 and 30 days have been tabulated in table 1 and 2 . The Phosphorous also enhanced in the period of composting. Raw coir pith was $0.85 \%$ and when the course of composting it is enhanced to $1.77 \%$ and $2.08 \%$ for Azotobacter vinelandii and Azospirillum brasilense respectively. The increase of Potassium also observed to $0.22 \%$ and $0.19 \%$ for the two organisms from $0.04 \%$ which is for the raw coir pith. There was a reduction observed in the Organic Carbon content from $7.34 \%$ to $6.15 \%$ and $4.80 \%$ for both the nitrogen fixing organisms.

Nitrogen fixation is the reduction of atmospheric nitrogen to ammonia. The capacity for nitrogen fixation is widespread among bacteria and archaea. A reduction in ammonia in the compost is evident during nitrogen fixation and in the present study a definite increase of ammonia in the compost was observed. In raw coir pith $1261.16 \mathrm{mg} / \mathrm{kg}$ ammonia was present, but during composting the amount was enhanced to $2812.23 \mathrm{mg} / \mathrm{kg}$ for the period of 45 days composting in the case of Azotobacter vinelandii and for Azospirillum brasilense, it is 2927.81 $\mathrm{mg} / \mathrm{kg}$. There is a definite increase of ammonia, during composting of every 10, 20, 30 and 45days. The results confirm that nitrogen fixation is carried out very efficiently in the organisms which utilized the coir pith as substrate for growth.

The studies of Nitrogen fixation by the bacteria in soil are diverse but the same on other substrates is very limited. From the rhizosphere of mangrove areas, two new nitrogen fixing bacteria were isolated by Gina et al, 1992. Here in our studies, the efficacy of two nitrogen fixing bacteria viz. Azotobacter vinelandii and Azospirillum brasilense in the coir pith, were studied. Nitrogen fixation in A.vinelandii is complicated by the presence of three biochemically and genetically distant nitrogenase enzymes, each of which is synthesized under different conditions of metal supply. Besides nitrogen fixation, A.vinelandii also produces thiamine, riboflavin, indole acetic acid and gibberellins. When Azotobacter is applied to seeds, seed germination is improved to a considerable extent, so also it controls plant diseases due to above substances produced by A.vinelandii (Kader et al, 2002)

Any Organic fertilizer typically provides three primary macronutrients such as Nitrogen, Phosphorous and Potassium. Use of biofertilizers is one of the important components of integrated nutrient management, as they are cost effective and renewable source of plant nutrients to supplement the chemical fertilizers for 
Table 1. Nitrogen, Phosphorous and Potassium content of raw and biodegraded coir pith with Azotobacter vinelandii

\begin{tabular}{|c|l|c|c|c|c|c|}
\hline $\begin{array}{c}\text { Sl } \\
\text { No }\end{array}$ & \multicolumn{1}{|c|}{ Samples } & $\begin{array}{c}\text { Composting } \\
\text { Days }\end{array}$ & $\begin{array}{c}\text { Nitrogen } \\
\mathbf{( \% )}\end{array}$ & $\begin{array}{c}\text { Phosphorous } \\
\mathbf{( \% )}\end{array}$ & $\begin{array}{c}\text { Potassium } \\
\mathbf{( \% )}\end{array}$ & $\begin{array}{c}\text { Organic } \\
\text { Carbon } \\
(\%)\end{array}$ \\
\hline 1 & Raw Coir pith & 0 & 0.19 & 0.85 & 0.04 & 7.34 \\
2 & Coir pith + A.vinelandii & 10 & 0.29 & 1.48 & 0.13 & 6.94 \\
3 & Coir pith + A.vinelandii & 20 & 0.38 & 1.52 & 0.15 & 6.64 \\
4 & Coir pith + A.vinelandii & 30 & 0.68 & 1.71 & 0.19 & 6.34 \\
5 & Coir pith + A.vinelandii & 45 & 0.70 & 1.77 & 0.22 & 6.15 \\
\hline
\end{tabular}

Table 2. Nitrogen, Phosphorous and Potassium content of raw and biodegraded coir pith with Azospirillum brasilense

\begin{tabular}{|c|l|c|c|c|c|c|}
\hline $\begin{array}{c}\text { Sl } \\
\text { No }\end{array}$ & \multicolumn{1}{|c|}{ Samples } & $\begin{array}{c}\text { Composting } \\
\text { Days }\end{array}$ & $\begin{array}{c}\text { Nitrogen } \\
\mathbf{( \% )}\end{array}$ & $\begin{array}{c}\text { Phosphorous } \\
\mathbf{( \% )}\end{array}$ & $\begin{array}{c}\text { Potassium } \\
\mathbf{( \% )}\end{array}$ & $\begin{array}{c}\text { Organic } \\
\text { Carbon } \\
(\%)\end{array}$ \\
\hline 1 & Raw Coir pith & 0 & 0.19 & 0.85 & 0.04 & 7.34 \\
2 & Coir pith+A.brasilense & 10 & 0.38 & 0.89 & 0.06 & 6.41 \\
3 & Coir pith+A.brasilense & 20 & 0.48 & 1.21 & 0.08 & 5.67 \\
4 & Coir pith+A.brasilense & 30 & 0.50 & 2.02 & 0.15 & 4.85 \\
5 & Coir pith+A.brasilense & 45 & 0.61 & 2.08 & 0.19 & 4.80 \\
\hline
\end{tabular}

Table 3. Ammonia content of raw and biodegraded coir pith with Azotobacter vinelandii and Azospirillum brasilense

\begin{tabular}{|c|c|c|c|c|}
\hline SI no & $\begin{array}{c}\text { Composting } \\
\text { Days }\end{array}$ & \multicolumn{3}{|c|}{ Amount of Ammonia (mg/kg) } \\
\hline & & Raw coir pith & $\begin{array}{c}\text { Coir pith }+ \\
\text { Azotobacter vinelandii }\end{array}$ & $\begin{array}{c}\text { Coir pith }+ \\
\text { Azospirillum brasilense. }\end{array}$ \\
\cline { 3 - 5 } & & 1261.16 & 1261.16 & 1261.16 \\
2 & 0 & 1261.16 & 1517.17 & 1621.12 \\
3 & 10 & 1261.16 & 1981.22 & 2028.80 \\
4 & 20 & 1261.16 & 2430.12 & 2442.86 \\
5 & 30 & 1261.16 & 2812.23 & 2927.81 \\
\hline
\end{tabular}


Cord 2011, 27 (2)

Figure 1. Enhancement of Nitrogen in Composting Process

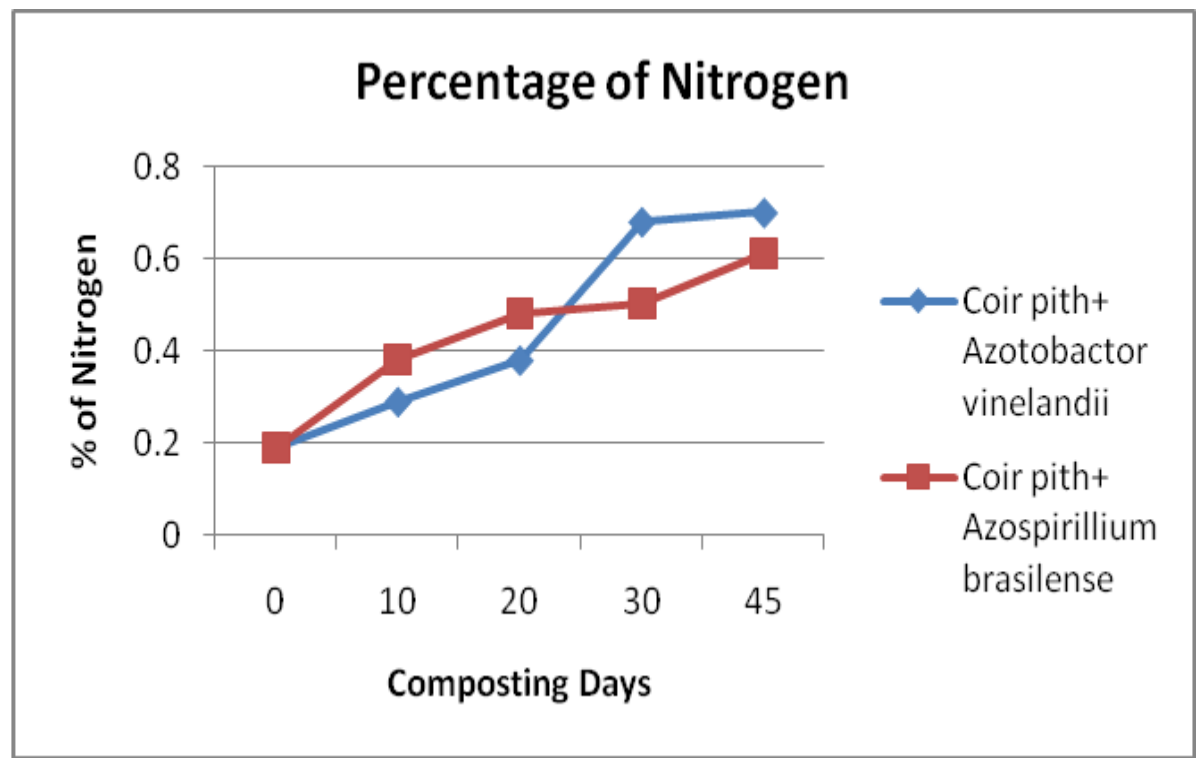

Figure 2. Enhancement of Phosphorous Composting Process

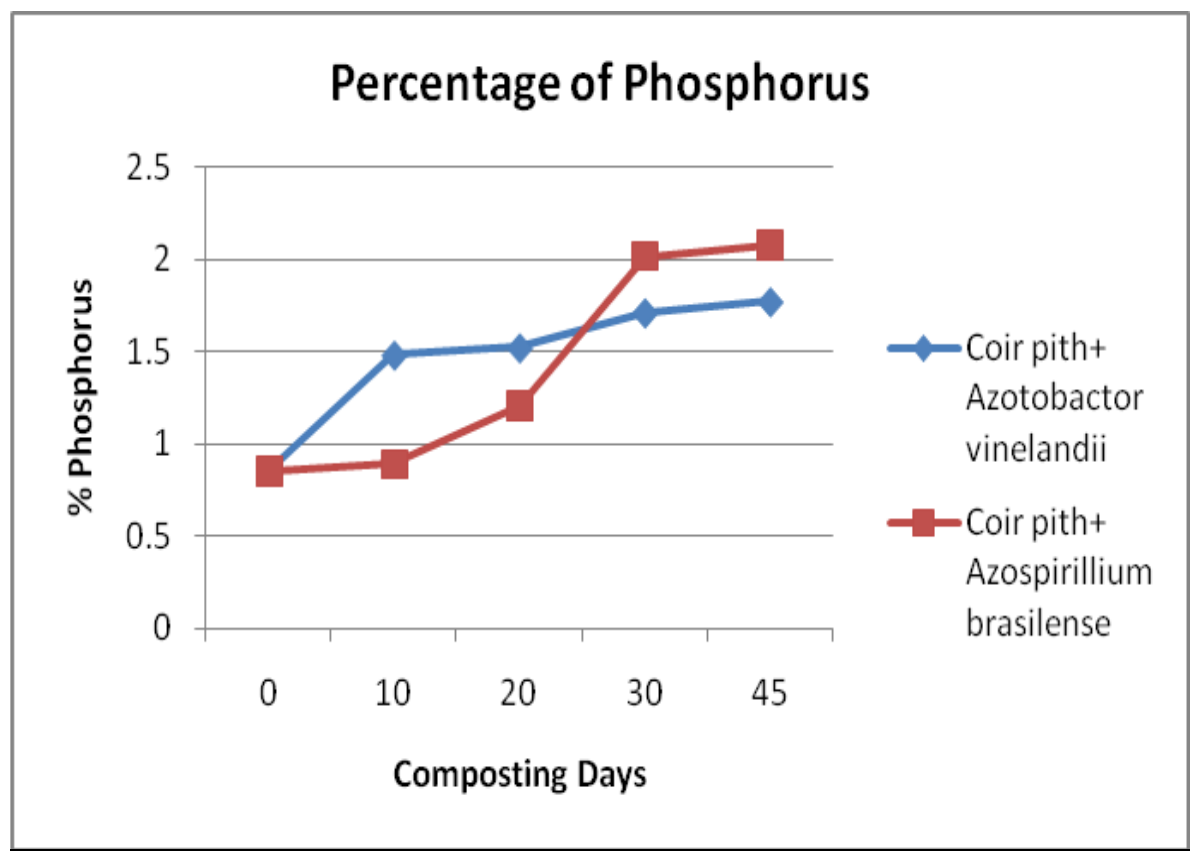


Cord 2011, 27 (2)

Figure 3. Enhancement of Potassium in Composting Process

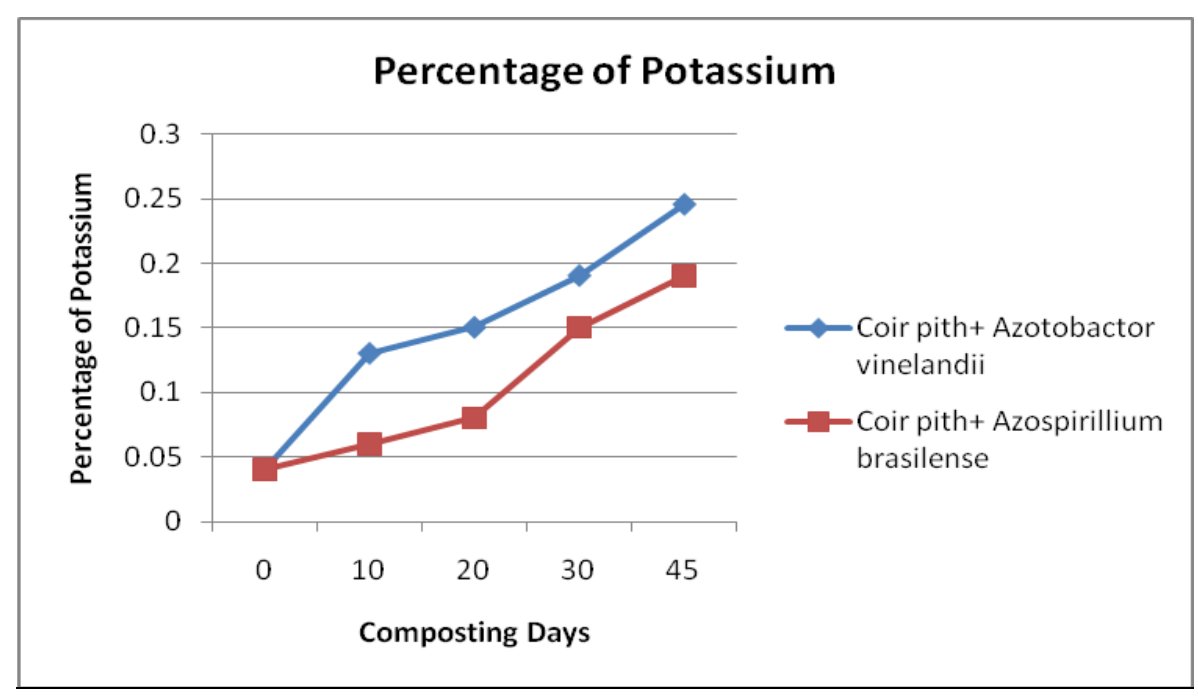

Figure 4. Enhancement of Ammonia in Composting Process

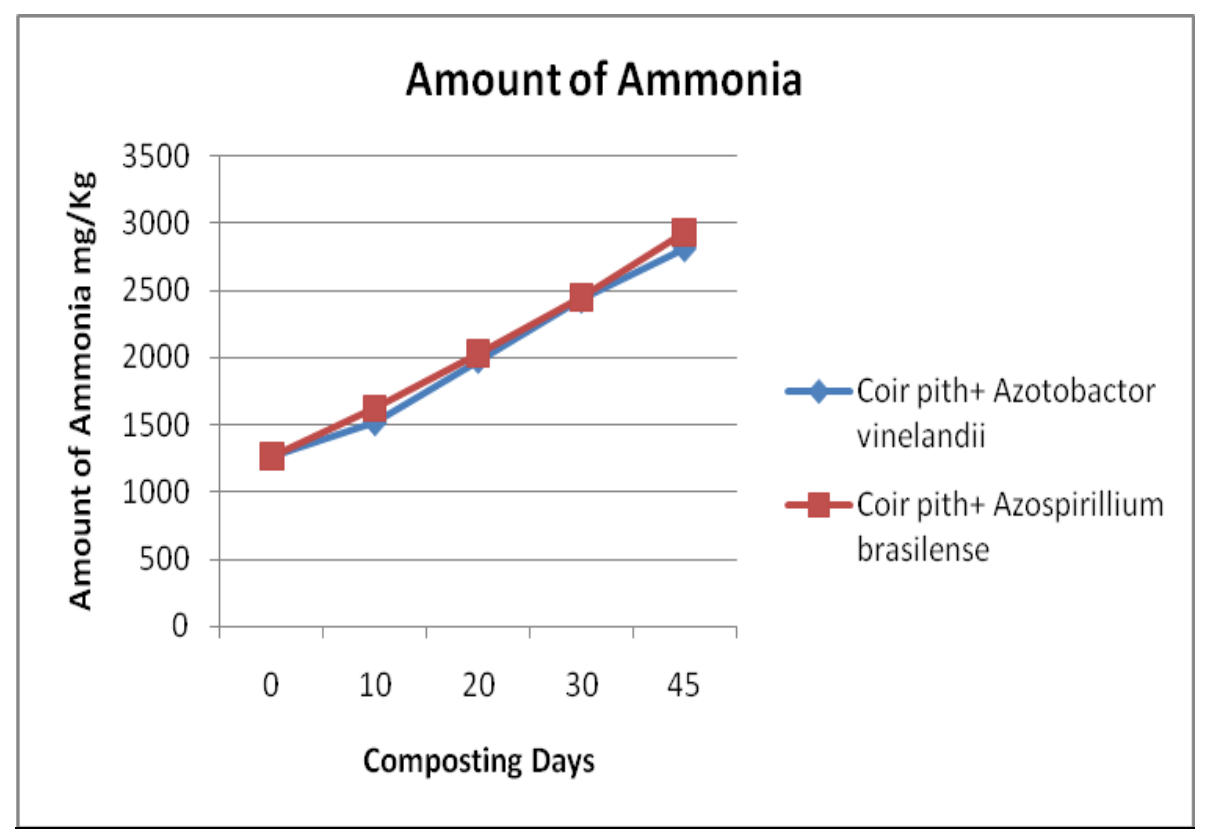


sustainable agriculture (Mishra \& Dadhach., 2010). In our studies, the enhancement of Nitrogen in coir pith after the composting is very evident. Nitrogen fertilizers are one of the most widely used chemical fertilizers, as deficiency of nitrogen in the soil often limits crop yields. Consumption of nitrogen fertilizer in Asia has increased from 1.5 to 47 million tons during the last 35 years (Dawe, 2000). In general, less than $50 \%$ of the added nitrogen is available to the plants. Biological nitrogen fixation, the enzymatic reduction of nitrogen to ammonia, replenishes the loss of nitrogen from soil-plant ecosystems. Soil diazotrophs are the main source of nitrogen input in primary production ecosystems (Cleveland et al, 1999)

The moisture content of coir pith were kept high $(200 \%)$ in all the heaps during composting, which may help nitrogen fixing organism for their growth and action. Raw coir pith is very poor in nitrogen content, $\mathrm{C}: \mathrm{N}$ ratio mounting to 112:1 (Nagarajan et al, 1985). Such a high $\mathrm{C}$ : $\mathrm{N}$ ratio is undesirable for any organic waste for application as organic manure in agricultural farms because it causes deleterious effects to the crops. The results of the present study find application of coir pith which acts as the substrate for the nitrogen fixing organisms; it can enhance the fixation process in coir pith itself and thereby enrich the coir pith with nitrogen. From the earlier studies, the use of these same organisms was reported to cause the reduction of lignin in coir pith. So, it could be established that the use of these nitrogen fixing agents, can enhance the content of NPK which enables its use as effective Organic manure.

\section{Conclusions}

Nitrogen fixing bacteria are excellent and eco-friendly micro agents for the degradation of coir pith. From the earlier studies, coir pith is not an efficient medium for most of the microorganisms, but our study confirms the efficacy of coir pith for the growth of nitrogen fixing organisms, and thereby we can use the nitrogen fixing bacteria for the degradation of coir pith effectively. The final product also can be used for many plants as effective organic manure. This study will encourage the use of coir pith as organic manure for cultivation purposes and which will also help to minimize the problems relating to accumulation of this natural waste material in coir based industries.

\section{Acknowledgement}

First author thanks Prof N Chandramohanakumar, Rajiv Gandhi Chair in Contemporary Studies (RGCCS) for permission to carry out this investigation. Authors also thank Mr. Arun Augustine and Mrs. Kala K Jacob and Mrs. Pillai Raji. K, RGCCS for continuous encouragement and support.

\section{Reference}

Anandharaj, B (2007). Studies on coir pith based cyanobacterial biofertilizer for field cultivation (Dissertation), Bharathidasan University, Tiruchirappalli.

Bashan Y \& Holguin G (1997) Azospirillumplant relationship: environmental and physiological advances. Can J Microbiol 43:103-121.

Bürgmann H, Manuel Pesaro, Franco Widmer and Josef Zeyer (2003). Strategy for optimizing quality and quantity of DNA extracted from soil. Bacteriological Reviews, vol.36, No.2 p.295-341.

Church M J, Cindy M. Short, Bethany D. Jenkins, David M. Karl, and Jonathan P. Zehr, (1999). Temporal Patterns of Nitrogenase Gene (NifH) Expression in the Oligotrophic North Pacific Ocean' Ocean Sciences Department, Environmental Microbiology, Vol 134, No.1 p.155-193.

Cleveland, C.C et al., (1999) Global patterns of terrestrial biological nitrogen (N2) fixation in natural ecosystems. Global Biogeochem. Cycle, 13; 623-645.

Dawe, D., The potential role of biological nitrogen fixation in meeting future demand for rice and fertilizer. In The Quest for Nitrogen Fixation in rice (eds Ladha, J.K. and Reddy, P.M), International Rice 
Research Institute, Makati City, 2000, pp. $1-9$.

Ghosh, P.K., Sarma, U.S., Das, A.R., Radhakrishnan, S, and Ghosh, P, (2007). A novel method for accelerating composting of coir pith, Energy \& Fuels., 21:822-827.

Gina Holguin M, Antonia Guzman and Yoav Bashan (1992). Two new nitrogen fixing bacteria from the rhizosphere of mangrove trees: Their isolation, identification and in vitro interaction with rhizosphere Staphylococcus sp.

Hans Brintzinger (1966). Formation of Ammonia by insertion of molecular nitrogen into metal-hydride bonds. III. Consideration on the properties of enzymatic nitrogen fixing systems and proposal of a general mechanism. Biochemistry. 5; 3947-3950.

Hume, E.P (2007)., Cocopeat-A by product of coconut fibre industry. Madras Agric. J. 36-38

Janshekar, H \& Fiechter, A. (1981). On the bacterial degradation of lignin. Applied microbiology and biotechnology., 14: 4750 .

Kader, M.A, Mian, M.H, Hoque, M.S (2002). Effect of Azotobacter inoculants on the yield and nitrogen uptake by wheat. Department of Soil science, Bangladesh Agricultural University, Mymensigh, Bangladesh. 2(4): 251-261.

Mishra, B. K \& Dadhich, S. K (2010). Methodology of Nitrogen biofertilizer production. J. Adv. Dev. Res., 1:3-6.

Nagarajan R, Manikkam T S, Kothandarajan G $\mathrm{V}$ (1985) Manurial value of coir pith. Madras Agric J 72; 533-535.

Newton J.W and Cavins J.F (2003). Liberation of ammonia during nitrogen fixation by facultatively heterotrophic cyanobacterium. Elsevier B.V. 809; 44-50

Poly, F., Lionel Ranjard., Sylvie Nazaret., Francois Gourbiere \& Lucile Jocteur Monrozier. (2001). Comparison of nifH gene pools in soil and soil microenvironments with contrasting properties. Applied and Environmental Microbiology., 67:2255-2262.

Prabha, D.S., Karthikeyan, K., Navanietha Krishnaraj, R.,Akila,B.M., Hemanth, S., Harikrishnan, R., Archunan,G., Malliga,P., (2009), Effect of phenolic compounds released during degradation of coir pith by Oscillatoria annae on Albino rat (Rattus norvegicus)., J. Appl. Sci. Environ. Manage., 13(4):87-90

Ramalingam A, Gangatharan $M$ and Kasthuribain R. (2004) Solid waste biotreatment of coir pith and paddy straw, Asian J Microbiol, Biotechnol Environ Sci, 6:141-142.

Reghuvaran A, Ravindranath A D, Natarajan P \& Augustine A, Substitution of Urea with fungi and nitrogen fixing bacteria for composting coir pith, Madras Agric J, 96 (2009) 144-149.

Rubio, Jiang, X \& Pogliano, K. (2005). Localization of complex components in Bacillus subtilis: enrichment of the signal recognition particle receptor at early sporulation septa. J Bacteriol. 187:50005002 .

Sabra W. A, Zeng A. P, Lunsdorf H \& Deckwer W. D (2000). Effect of oxygen on formation and structure of Azotobacter vinelandii: alginate and its role in protecting nitrogenase. Appl. Environ. Microbiol., 66:4037-4044.

Sarita, S., Priefer, U. B., Prell, J \& Sharma, P. K. (2008). Diversity of nif $\mathrm{H}$ gene amplified from rhizosphere soil DNA. Curr. Sci. Idia. 94:109-115.

Stewart, W.D.P (1974). Nitrogen fixation in the sea. P. 537-564. In J.D. Costlow(ed.). Fertility of the sea. Gordon and Breach Science Publishers, London.

Vijaya D, Padmadevi S.N, Vasandha S, Meerabhai R.S \& Chellapandi P (2008) Effect of vermicomposted coir pith on the 
growth of Andrographis paniculata. Journal of Organic systems. 3:51-56.

Vinodhini S, Gnanambal V.S, Sasikumar J M and Padmadevi S N. (2005). Growth of two medicinal plants using biodegraded coir pith, Plant Archives, 5:277-280.

Vogel A I, A Text book of Quantitative Inorganic Analysis (ELBS and Longman, UK) 1961, 943-945.

Walkey, Black C A, (1934). An examination of the Degtjreff method for determining soil organic matter and a proposed modification of chromic acid and titration method. Soil Sci, 37; 29-38.
Waterbury, J.B., C.B. Calloway and R. D. Turner. (1983). A cellulolytic nitrogenfixing bacterium cultured from the gland of Deshayes in shipworms (Bivalvia: Teredinidae). Nature (London). 221:14011403.

Young, J. P. W. (1992). Phylogenetic classification of nitrogen fixing organisms. p. 43-86. In G. Stacey, R. H. Burris and H. J. Evans (ed). Biological nitrogen fixation. Chapman and Hall, New York. N.Y.

Zehr, J. P., M. T. Mellon \& S. Zani. (1998). New nitrogen fixing microorganisms detected in oligotrophic oceans by amplification of nitrogenase (nifH) genes. Appl. Environ. Microbiol. 64:3444-3450. 